Supplement of Geosci. Model Dev., 8, 1047-1070, 2015

http://www.geosci-model-dev.net/8/1047/2015/

doi:10.5194/gmd-8-1047-2015-supplement

(C) Author(s) 2015. CC Attribution 3.0 License.

(c) (i)

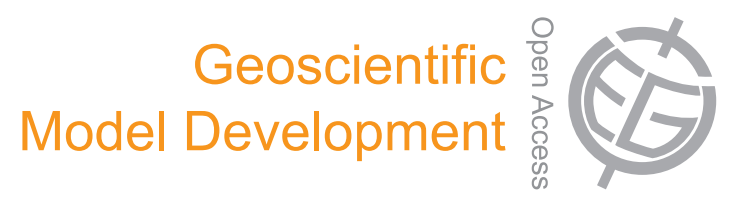

Supplement of

\title{
Dynamic model evaluation for secondary inorganic aerosol and its precursors over Europe between 1990 and 2009
}

S. Banzhaf et al.

Correspondence to: S. Banzhaf (sabine.banzhaf@met.fu-berlin.de) 
Table S1. Annual total emissions of $\mathrm{SO}_{2}, \mathrm{NO}_{\mathrm{x}}$ and $\mathrm{NH}_{3}$ for the years 1990, 1995, 2000, 2005 and 2010 of the EU-27+ member States and from International shipping (sum of annual total emissions from the Baltic Sea, the North-East Atlantic Ocean, the North Sea, the Mediterranean Sea and the Black Sea).

\begin{tabular}{|c|c|c|c|}
\hline $\begin{array}{l}\text { Emissions } \\
\left(\text { kton } \mathrm{a}^{-1}\right)\end{array}$ & Year & $\begin{array}{c}\text { EU-27+ } \\
\text { member States }\end{array}$ & $\begin{array}{c}\text { International } \\
\text { shipping }\end{array}$ \\
\hline \multirow[t]{5}{*}{$\mathrm{SO}_{2}$} & 1990 & 24518 & 1931 \\
\hline & 1995 & 15710 & 2190 \\
\hline & 2000 & 10621 & 2399 \\
\hline & 2005 & 8130 & 2714 \\
\hline & 2010 & 4393 & 2549 \\
\hline \multirow[t]{5}{*}{$\mathrm{NO}_{\mathrm{x}}$} & 1990 & 17393 & 2774 \\
\hline & 1995 & 16254 & 3146 \\
\hline & 2000 & 12416 & 3510 \\
\hline & 2005 & 11352 & 3876 \\
\hline & 2010 & 8898 & 4271 \\
\hline \multirow[t]{5}{*}{$\mathrm{NH}_{3}$} & 1990 & 4725 & - \\
\hline & 1995 & 4133 & - \\
\hline & 2000 & 4126 & - \\
\hline & 2005 & 3933 & - \\
\hline & 2010 & 3820 & - \\
\hline
\end{tabular}



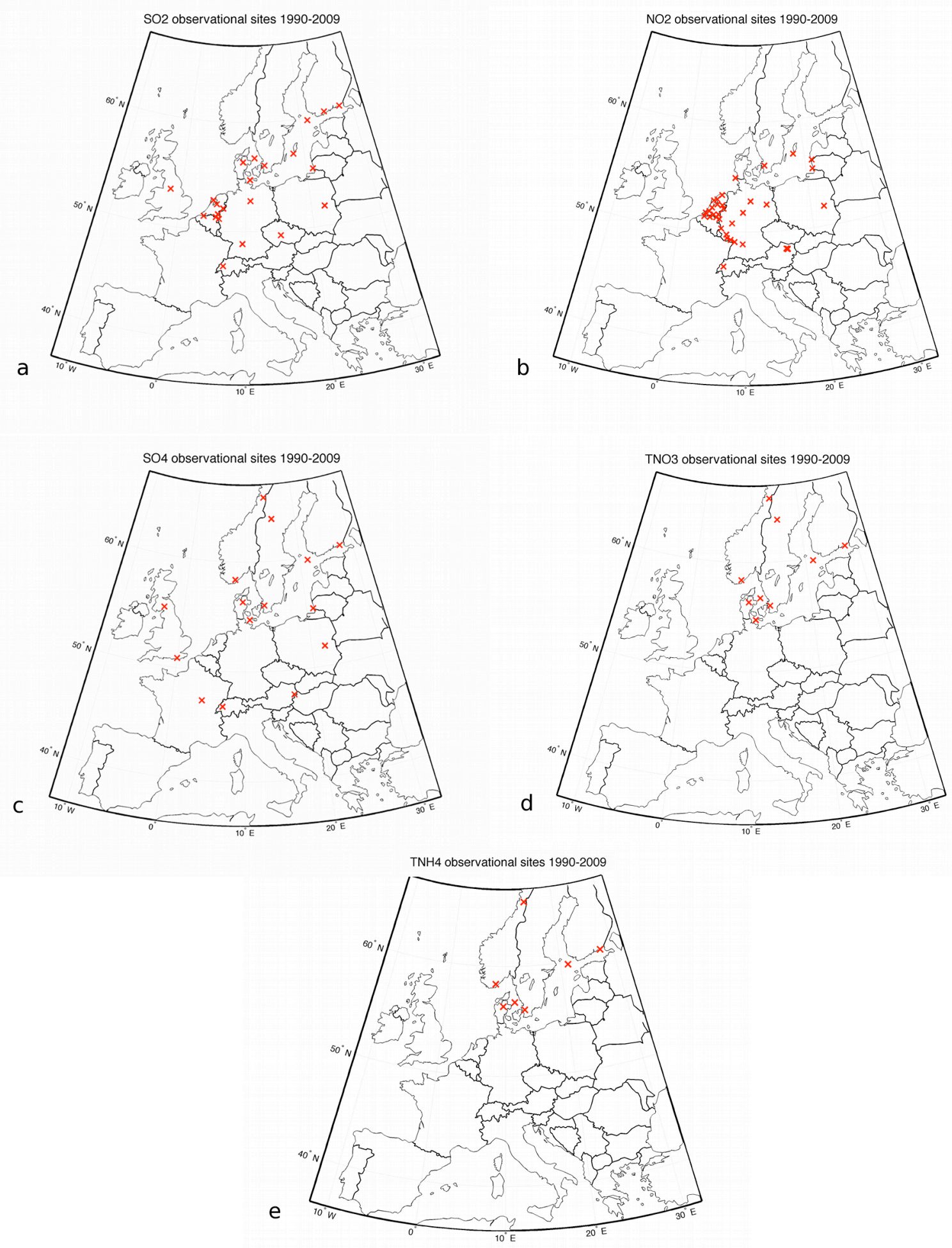

Figure S1. Locations of the observational sites used for the analysis of the different components for the 1990 to 2009 time period. 

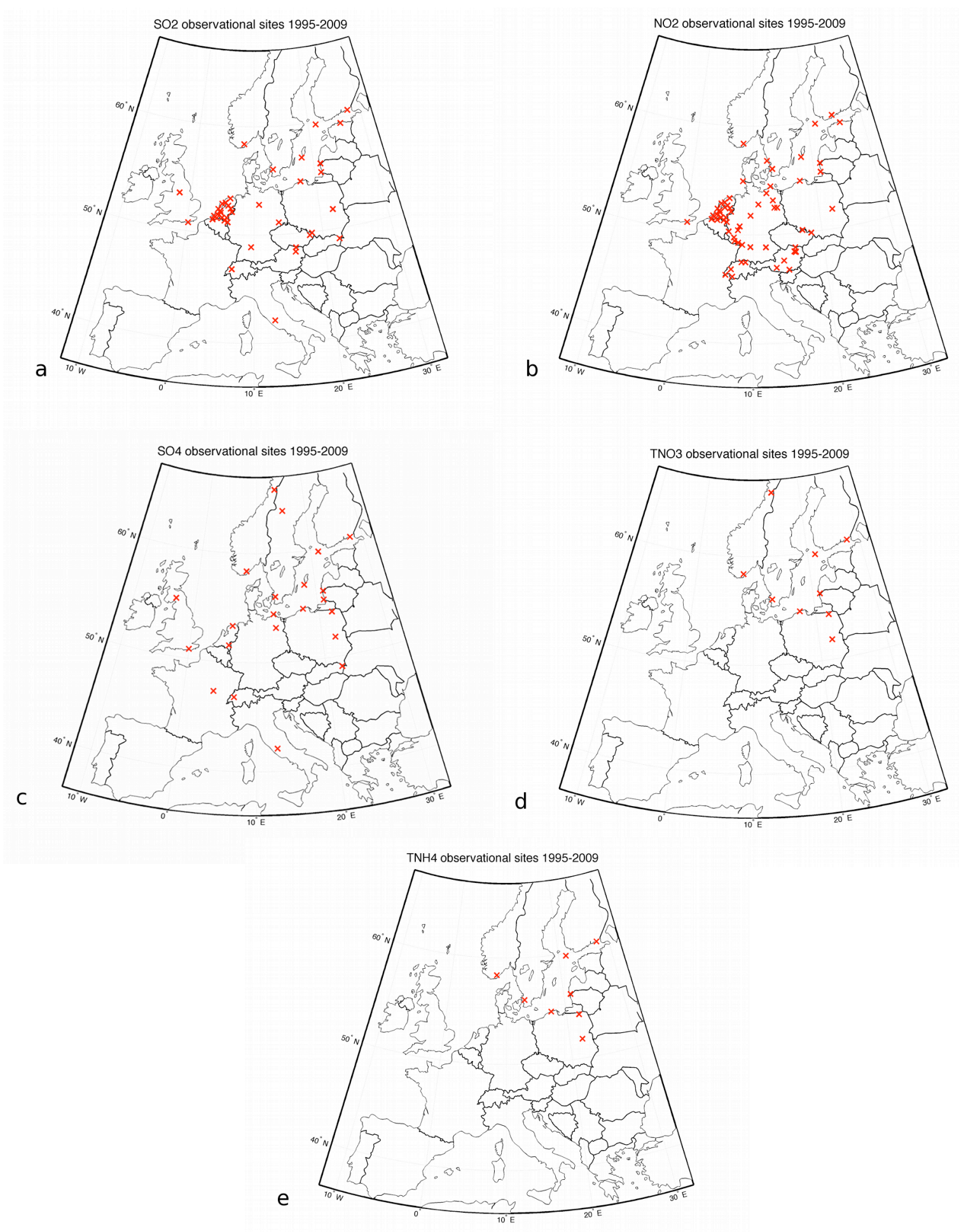

Figure S2. As Figure S1 for the 1995 to 2009 time period 
a

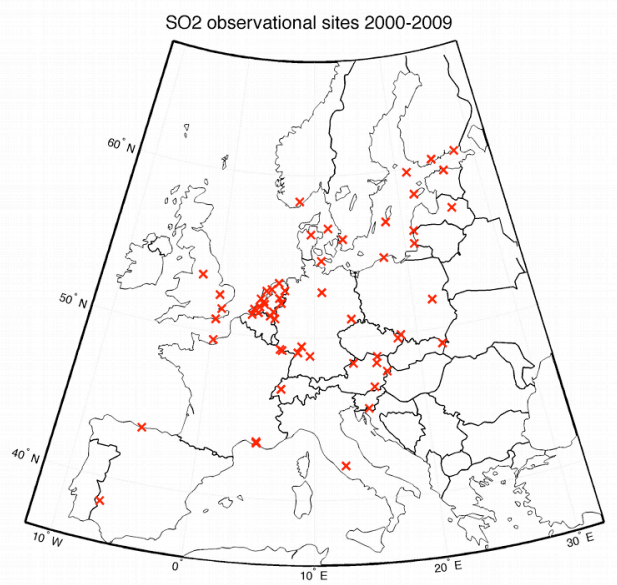

C

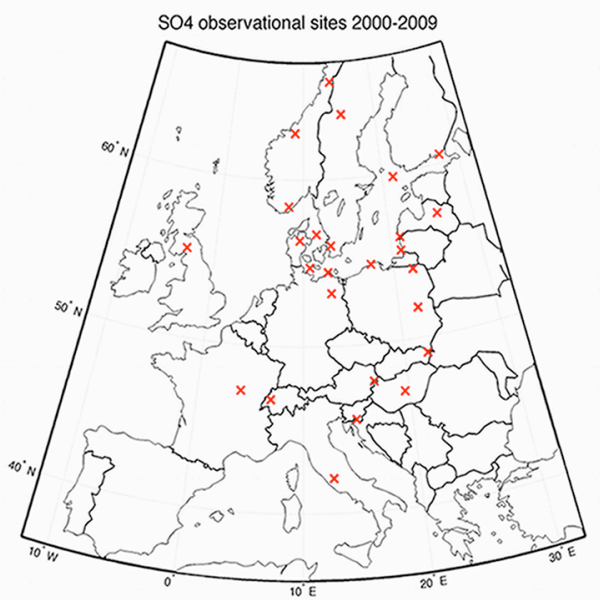

b
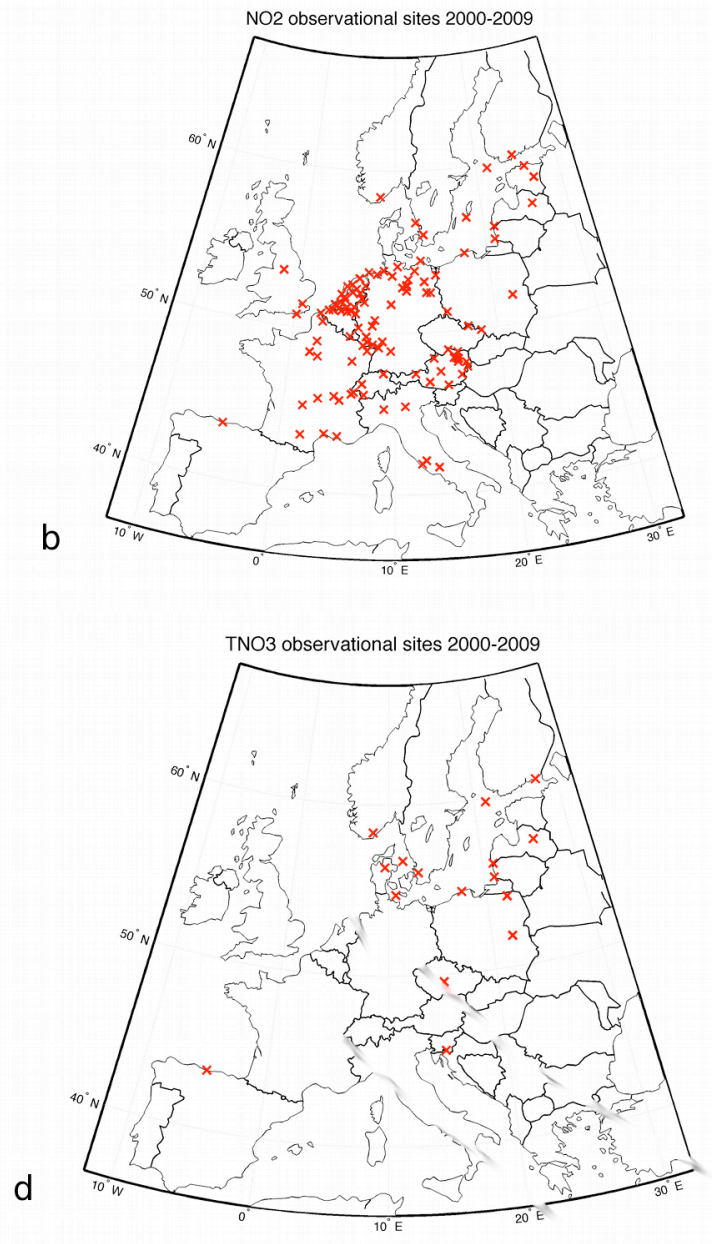

e

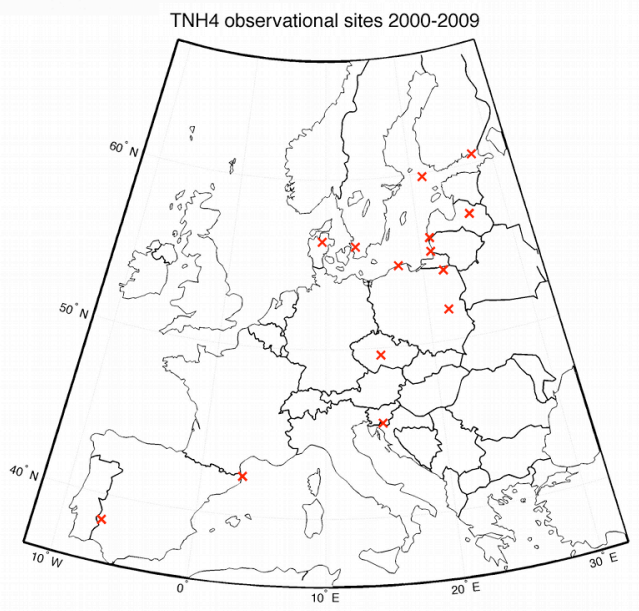

Figure S3. As Figure S1 for the 2000 to 2009 time period 

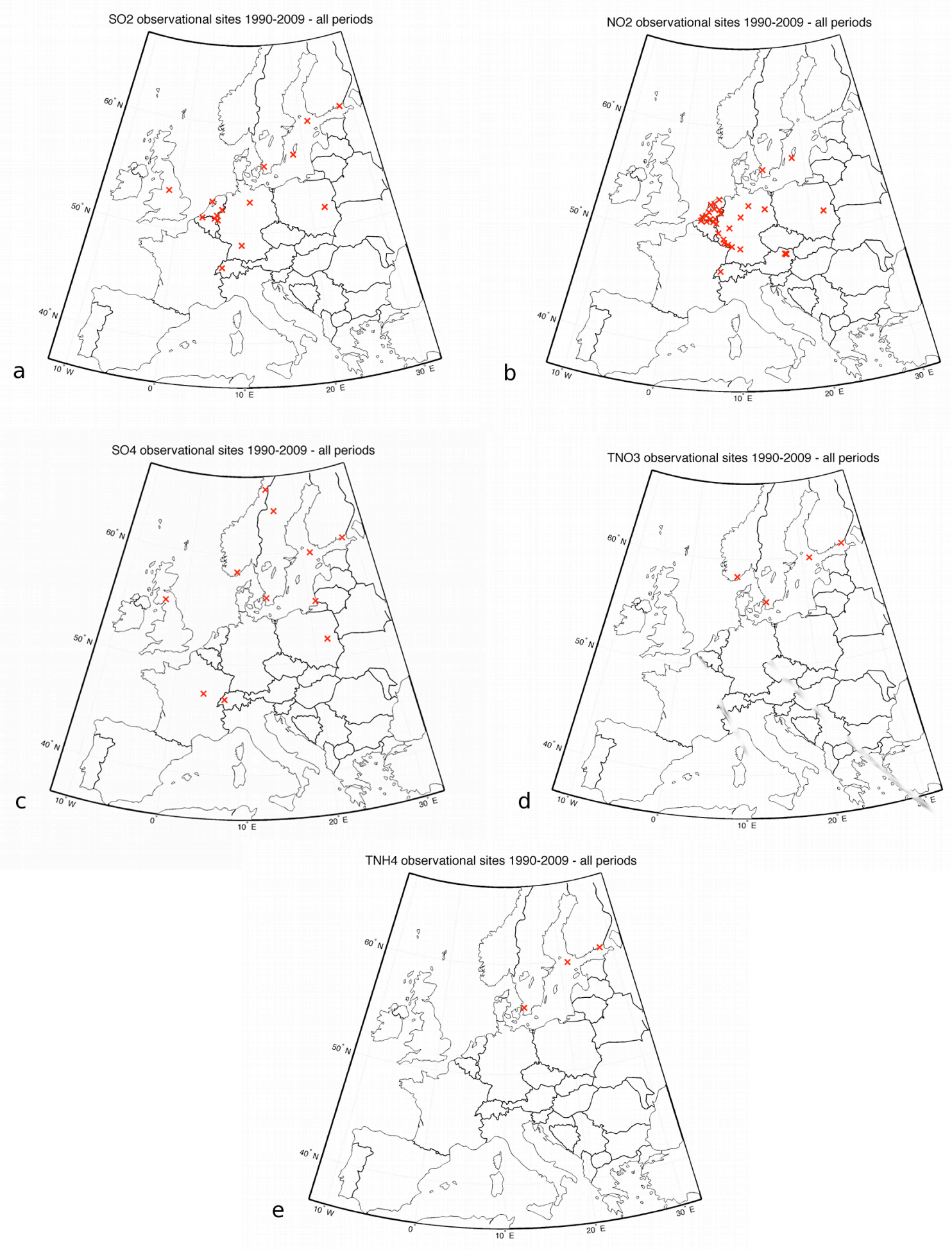

Figure S4. Locations of the observational sites used for the analysis of the different components when considering only those stations that pass the data selection criteria for all three periods. 
Table S2. Number of stations and derived observed and modelled absolute $\left(\mu \mathrm{g} \mathrm{m}^{-3} \mathrm{a}^{-1}\right)$ and relative (\% $\mathrm{a}^{-1}$ ) median trends for $\mathrm{SO}_{2}, \mathrm{NO}_{2}$ and $\mathrm{SO}_{4}{ }^{2-}$ at those stations that passed the selection criteria presented in Section 2.2.1 for all three time periods.

\begin{tabular}{|c|c|c|c|c|}
\hline Period & Evaluation & $\mathrm{SO}_{2}$ & $\mathrm{NO}_{2}$ & $\mathrm{SO}_{4}$ \\
\hline all & number of stations & 15 & 33 & 11 \\
\hline \multirow[t]{4}{*}{ 1990-2009 } & Observed abs. median trend & -0.41 & -0.37 & -0.11 \\
\hline & Modelled abs. median trend & -0.36 & -0.48 & -0.06 \\
\hline & Observed rel. median trend & -4.52 & -1.89 & -3.10 \\
\hline & Modelled rel. median trend & -4.16 & -2.46 & -2.33 \\
\hline \multirow[t]{4}{*}{$1995-2009$} & Observed abs. median trend & -0.28 & -0.34 & -0.09 \\
\hline & Modelled abs. median trend & -0.19 & -0.58 & -0.05 \\
\hline & Observed rel. median trend & -5.16 & -1.69 & -3.37 \\
\hline & Modelled rel. median trend & -4.83 & -2.70 & -2.33 \\
\hline \multirow[t]{4}{*}{ 2000-2009 } & Observed abs. median trend & -0.10 & -0.14 & -0.05 \\
\hline & Modelled abs. median trend & -0.09 & -0.35 & -0.03 \\
\hline & Observed rel. median trend & -4.46 & -1.07 & -3.07 \\
\hline & Modelled rel. median trend & -4.69 & -2.40 & -2.10 \\
\hline
\end{tabular}




\section{Sensitivity of resultant observed trends to data selection}

Following the guidance of the European Environment Agency one of the data selection criteria listed in section 2.2.1 was that at least $80 \%$ of the annual time series of observations must be available at each site. In this section we would like to test the sensitivity of the resultant observed median trends to that selection criterion. Table S3 shows the number of stations and the observed median trends for all considered species for the selection criteria that at least $16(=80 \%), 17,18,19$ or 20 years of the annual time series of observations must be available for the 1990-2009 time period. As already for the least stringent criterion we start with a small amount of stations for $\mathrm{TNO}_{3}$ and $\mathrm{TNH}_{4}$ concentrations and all stations are located in northern Europe, there is hardly any or no change in median trends when using a different number of available years for these components. For $\mathrm{SO}_{2}, \mathrm{NO}_{2}$ and $\mathrm{SO}_{4}$ concentrations Table S3 shows that even though the sign is robust the selection criterion does impact the observed median trends as a result of a changing number of considered stations. The differences are smallest between choosing 16 or 17 years as selection criterion. The most stringent criterion of 20 years $(=100 \%)$ significantly reduces the number of considered stations. Although the completeness of the time series increases the robustness of the trend assessment at the single stations, the overall assessment gets less representative for Europe as the number of stations is considerably lower.

Table S3. Number of stations and the corresponding observed median trend for different selection criteria varying the amount of required years of the annual time series

\begin{tabular}{|c|c|c|c|c|c|c|c|c|c|c|}
\hline 1990- & $\mathrm{SO}_{2}$ & & $\mathrm{NO}_{2}$ & & $\mathrm{SO}_{4}$ & & $\mathrm{TNO}_{3}$ & & $\mathrm{TNH}_{\mathrm{H}}$ & \\
\hline \#years & \#stations & $\begin{array}{l}\text { Median } \\
\text { trend } \\
\left(\mu \mathrm{g} \mathrm{m}^{-3} \mathrm{a}^{-1}\right)\end{array}$ & \#stations & $\begin{array}{l}\text { Median } \\
\text { trend } \\
\left(\mu \mathrm{g} \mathrm{m}^{-3} \mathrm{a}^{-1}\right)\end{array}$ & \#stations & $\begin{array}{l}\text { Median } \\
\text { trend } \\
\left(\mu \mathrm{g} \mathrm{m}^{-3} \mathrm{a}^{-1}\right)\end{array}$ & \#stations & $\begin{array}{l}\text { Median } \\
\text { trend } \\
\left(\mu \mathrm{g} \mathrm{m}^{-3} \mathrm{a}^{-1}\right)\end{array}$ & $\begin{array}{l}\text { \#stati } \\
\text { ons }\end{array}$ & $\begin{array}{l}\text { Median } \\
\text { trend } \\
\left(\mu \mathrm{g} \mathrm{m}^{-3} \mathrm{a}^{-1}\right)\end{array}$ \\
\hline 16 & 23 & -0.343 & 37 & -0.363 & 15 & -0.156 & 9 & $-6 \times 10^{-3}$ & 7 & $-2.7 \times 10^{-2}$ \\
\hline 17 & 21 & -0.345 & 37 & -0.363 & 14 & -0.147 & 7 & $-6 \times 10^{-3}$ & 5 & $-2.7 \times 10^{-2}$ \\
\hline 18 & 20 & -0.302 & 36 & -0.368 & 11 & -0.110 & 6 & $-9 \times 10^{-3}$ & 3 & $-2.7 \times 10^{-2}$ \\
\hline 19 & 14 & -0.247 & 28 & -0.368 & 9 & -0.110 & 5 & $-6 \times 10^{-3}$ & 3 & $-2.7 \times 10^{-2}$ \\
\hline 20 & 7 & -0.234 & 12 & -0.381 & 7 & -0.101 & 3 & $-6 \times 10^{-3}$ & 3 & $-2.7 \times 10^{-2}$ \\
\hline
\end{tabular}

